\title{
ANTI-LEPTOSPIRE AGGLUTININS IN EQUINE SERA, FROM SÃO PAULO, GOIAS, AND MATO GROSSO DO SUL, BRAZIL, 1996-2001.
}

\author{
LANGONI H. ${ }^{1}$, DA SILVA A.V. ${ }^{1}$, PEZERICO S.B. ${ }^{1}$, DE LIMA V.Y. ${ }^{1}$
}

\author{
${ }^{1}$ Zoonosis Searches Nucleus (NUPEZO), Departament of Veterinary Hygiene and Public Health, \\ School of Veterinary Medicine and Animal Husbandry (FMVZ), São Paulo State University \\ (UNESP), Botucatu, São Paulo, Brazil.
}

\begin{abstract}
Equine leptospirosis can present a non-symptomatic form, an acute clinical form, or even develop chronically, causing reproductive alterations, such as abortion and recurrent uveitis. Since the prevalence of leptospirosis in several countries and regions is widely reported, the objective of this study was to verify the prevailing equine leptospirosis in different regions of Brazil. Sera from 1402 blood samples from horses of different age, sex, breed, and purpose were examined. These samples came from southeastern and central west states of Brazil. The method utilized was the Microscopic Agglutination Test (MAT), with 12 different Leptospira serovars. From the sera tested, 754 (54\%) were positive for one (385) or more (372) serovars. These results were higher when compared to national and international levels. The most commonly found serovars were icterohaemorrhagiae (37.01\%), suggesting exposure to rodents, castellonis (16.97\%), and djasiman (15.19\%). There were significant differences of reagents between sexes, and a tendency toward higher positivity with age. Distribution of sera-reagents related to aptitude showed a markedly higher value for work animals than for sporting ones. Higher rates were found for animals with undefined breed. There were no significant differences related to regional origin. As an indication of multiple exposure, significant associations were observed between the following serovars: castellonis and djasiman; castellonis and grippotyphosa; castellonis and copenhageni; castellonis and icterohaemorrhagiae; castellonis and pomona; canicola and pomona; canicola and djasiman; djasiman and copenhageni; icterohaemorrhagiae and djasiman; icterohaemorrhagiae and pyrogenes; copenhageni and pomona. These results showed the necessity of further studies on the epidemiology of this disease in equines and its relationship to human illness.
\end{abstract}

KEY WORDS: Leptospira, horse, serology.

\section{CORRESPONDENCE TO:}

H. LANGONI - Departamento de Higiene Veterinária e Saúde Pública, Faculdade de Medicina Veterinária e Zootecnia, Distrito de Rubião Jr., s/n, 18.618-000, Botucatu, São Paulo, Brazil.

Phone: 55143811 6270. Fax: 551438116075.

Email: hlangoni@fmvz.unesp.br 


\section{INTRODUCTION}

Leptospiroses in equines can present a clinically non-symptomatic form, or develop to acute or chronic clinical form (13). The acute form, characterised by septicemia, encephalitis, and hepatonephritis is rare. Chronic manifestations are more frequent, with loss of weight, various degrees of conjunctivitis, ceratite, uveitis, and reproductive alterations, such as abortion (24).

The most commonly used method in the diagnostic laboratories is the microscopic seroagglutination test applying representative serovars strains as antigens. It is also used in investigating epidemics, since it indicates the serogroups present in a population (17).

Serologic research in equines has demonstrated that exposure to and consequent infection by this agent is distributed worldwide. The predominating serogroups varied with the leptospiric antigens utilized in the studies, and with geographic location (5), reflecting the animals exposure to serovars carried by other domestic or wild animals $(10,14)$.

Considering the variety prevalent in different countries, this study aimed to verify the presence of anti-Leptospira antibodies in equines from different states of Brazil, its relation with age, sex, origin, and aptitude, as well as to examine the seroconversion associations between pairs of serovars, as an indication of multiple exposure.

\section{MATERIAL AND METHODS}

\section{Samples}

Samples of equine sera from various states of the southeast and central-west of Brazil were examined and sent to the Laboratory of Zoonosis Diagnostic, Department of Hygiene and Public Health, School of Veterinary Medicine and Animal Husbandry, São Paulo State University (UNESP), Botucatu, São Paulo State, Brazil, for the Microscopic Agglutination Test (MAT), from 1996 to 2001.

From the 1402 samples of equine sera examined, 71 (5.06\%) were from males, 617 (44.01\%) from females, and 714 (50.93\%) had no information about the sex. The ages varied from 1 month to 19 years old. With regard to the aptitude, 445 (31.74\%) presented data, 138 were sporting animals, and 307 work animals. In relation to the breeds, 408 (29.10\%) horses had defined breed, mainly Quarter-horse, pure bred Arabian, and "Pantaneira”, a local breed of 
H. Langoni et al. ANTI-LEPTOSPIRE AGGLUTININS IN EQUINE SERA, FROM SÃO PAULO, GOIAS, AND MATO GROSSO DO SUL, BRAZIL, 1996-2001. J. Venom. Anim. Toxins incl. Trop. Dis., 2004, 10, 3, p.209.

western Mato Grosso state. In regard to the geographical origin, 659 samples were from São Paulo, 145 from Mato Grosso do Sul, 31 from Goiás, and the remainder, of unknown origin.

\section{Serologic Method}

The serologic test used was the MAT (11), utilizing the following serovars of Leptospira spp as antigens: bratislava, castellonis, djasiman, gryppotyphosa, copenhageni, icterohaemorraghiae, pomona, hardjo, wolffi, tarassovi, canicola, and pyrogenes. Agglutinations up to 1:100 sera dilution were considered positive.

\section{Statistical Analysis}

The association between the epidemiologic variables and the seroconvertion was evaluated using the Chi-square test, with $\alpha=0.05 \%$, utilizing the EpiInfo software, version 6.04 . The association between seroconversion in a horse at higher titers among those serovars, as an indication of multiple exposure, was evaluated using the Chi-square or the Fisher tests, depending on the number of observations. The titers higher than the top limit of the confidence interval of titers distribution for each serovar were considered high.

\section{RESULTS}

From the 1402 samples, 757 (54.0\%) were reagents, of which 385 reacted to one serovar only, and 372 reacted to more than one. Out of the positive animals, 520 (37.01\%) reacted to icterohaemorrhagiae serovar; 238 (16.97\%) to castellonis; 213 (15.19\%) to djasiman; 85 (6.06\%) to copenhageni; $63(4.49 \%)$ to hardjo; 61 (4.35\%) to wolffi; 52 (3.71\%) to gryppotophosa; and 36 (2.57\%) to bratislava. From the 269 samples tested against the canicola and pyrogenes serovars, 15 (5.58\%) and 41 (2.92\%) were reagents, respectively. For the pomona serovar, 76 (5.42\%) samples were positive, although five were not tested for this serovar. Only $21(1.50 \%)$ samples reacted against the tarassovi serovar, but, in this case, two samples were not tested. Table 1 shows the titers distribution among the reagent samples for each serovar.

There was a significant difference between the sexes $\left(\chi^{2}=6.42 ; \quad P=0.01 ; \quad O R=1.94\right.$; CI95\%=1.15-3.29), 379 (61.43\%) of the 617 females, and $32(45.17 \%)$ of the 71 males were 
positive. It was observed that a tendency to more positive reactions increased with age (Figure 1). The distribution of reagents related to the aptitude $\left(\chi^{2}=8.68 ; P<0.05\right.$; OR=1.88; CI95\%= 1.22-2.89) was significantly higher for work animals [192 (62.54\%)] than for sporting ones [65 (47.10\%)]. A significant difference was observed between the animals with known breed and those with undefined breed $\left(\chi^{2}=6.26 ; P=0.01\right.$; OR=1.35; CI95\%=1.07-1.71), and more reagents were found among the animals with undefined breed (51.81\%). There were no significant differences with regard to the geographical origin $\left(\chi^{2}=3.0 ; P=0.08\right.$; OR=1.4; CI95\% $=0.97-2.00)$.

Table 2 shows the significance of association between two serovars for samples with titers greater than the top limit of confidence interval of titer distribution. In all cases, except for pyrogenes, titers over 200 were considered high. In the case of pyrogenes, titers over 400 were considered high. As indicative of multiple exposure, significant associations between pairs of serovars were observed as follows: castellonis / djasiman; castellonis / gryppotyphosa; castellonis / copenhageni; castellonis / icterohaemorrhagiae; castellonis / pomona; canicola / pomona; canicola / djasiman; djasiman / copenhageni; icterohaemorrhagiae / djasiman; icterohaemorrhagiae / pyrogenes; djasiman / pomona and copenhageni / pomona. There were also significant associations between the serovars icterohaemorrhagiae and copenhageni, and hardjo and wolffi, belonging to the serogroups Icterohaemorrhagiae and Sejroe, respectively.

\section{DISCUSSION}

There are numerous reports of serologic studies on equine leptospirosis in several countries, demonstrating the importance of this infection in equines. Large occurrence of titers in apparently healthy animals suggests that the majority of the infections are non-symptomatic, with rapid elimination of the infecting serotype (14). Most of these studies denote the availability of laboratories, as well as private veterinary clinics that make these diagnoses (17).

Difficulty in interpreting serologic tests based on a single sample is reported, since the MAT results can be negative or low, during the acute phase of the illness, or in animals that aborted, 
H. Langoni et al. ANTI-LEPTOSPIRE AGGLUTININS IN EQUINE SERA, FROM SÃO PAULO, GOIAS, AND MATO GROSSO DO SUL, BRAZIL, 1996-2001. J. Venom. Anim. Toxins incl. Trop. Dis., 2004, 10, 3, p.211.

due to the interval between the infection and abortion (22). Thus, it is suggested that seropositive result is an evidence of exposure to the agent, but it does not confirm the disease (3). On experimental infection of five horses with L. interrogans serovar copenhageni, there was an increase of serologic titers from the $7^{\text {th }}$ day after the inoculation. The highest level was reached on the $18^{\text {th }}$ day, when the geometric titer averaged 4851.3. After the $24^{\text {th }}$ day of inoculation, the titers began to decrease, varying from 50 to 400. On day 100, the titers geometric level was 152.8. The infected horses presented clinical alterations, such as hyperthermia, anorexia, jaundice, petechial hemorrhages in the mouth, and recurrent uveitis (13).

The frequency of anti-Leptospira agglutinins (54.0\%) can be considered high, when compared to other studies in Brazil, where the prevalence of anti-Leptospira agglutinins and serovars varied according to the authors and regions (Table 3) $(1,2,6,7,12,15,18,20,25)$. However, higher prevalences were also reported in Britain, where anti-Leptospira antibodies were detected in 224 (55.4\%) serum samples sent to the laboratory, and in 173 (34.6\%) samples from animals destined to exportation. In both groups, bratislava serovar was prevalent (31.7 and $16.6 \%$, respectively). (14). In Ireland, reaction was detected in $72.2 \%$ of the 650 samples from mares, with prevalence of bratislava (59.1\%) (10).

In Canada, titers for the icterohaemorrhagiae, bratislava, copenhageni, and autumnalis serovars were commonly found, $94.6,56.6,46.5$, and $43.5 \%$, respectively (16). In the United States of America (USA), it was observed that 56\% of the 2967 positive animals reacted for one or more serovars, with prevalence of bratislava (4). In France, among 1645 horses, a prevalence of $67.0 \%$ was reported, with titers of 200 or over, and predominance of the Australis and Gryppotyphosa serogroups (21).

Prevalences inferior to those found in this study were observed in Australia, where $41.5 \%$ of 272 samples were positive and the most common reactions were for the serovars ballum (15.1\%), autumnalis (11.8\%), icterohaemorrhagiae (9.9\%), pomona (8.1\%), and hardjo (7.7\%) (24). Again, in that same country, it was found $28.57 \%$ positive from the 168 animals tested, with higher prevalence of the copenhageni (60.42\%), zanoni (31.25\%), tarassovi (27.08\%), and hardjo (22.91\%) serovars (09). In the USA, similar results were obtained for 
H. Langoni et al. ANTI-LEPTOSPIRE AGGLUTININS IN EQUINE SERA, FROM SÃO PAULO, GOIAS, AND MATO GROSSO DO SUL, BRAZIL, 1996-2001. J. Venom. Anim. Toxins incl. Trop. Dis., 2004, 10, 3, p.212.

the 669 horses examined, with 33.6\% of reagents and a higher occurrence of the bratislava serovar (22.3\%) (19).

However, considering the lack of definition for significant serologic titers of infection in the equine species (9), as well as the utilization of various Leptospira antigens, and the different geographic origins (14), it is difficult to compare results.

In the present work, greater response to icterohaemorrhagiae was observed (37.01\%), which was also found in other studies in Brazil $(1,7,18)$. Infection by the icterohaemorrhagiae serogroup is maintained by rodents that share the environment with equines, what can explain this response (16). The risk factors associated with equines exposure to the pomona, autumnalis, and bratislava serovars were studied in New York, and it was concluded that seroconversion of these serovars is also related to exposure to rodents (3).

Other animals may be a source of infection by Leptospira for the equine species, as evidenced in this study.

Great number of reactions to the castellonis serovar (16.97\%), which belongs to the Ballum group, emphasize the importance of the constant association between horses and bovines, since this serogroup is very common in that species (21). The same reason can explain the presence of the hardjo serovar (4.49\%), once bovines are responsible for maintaining it (10). Reaction to the canicola serovar (5.58\%) can be explained by the fact that horses are usually next to dogs, carriers of this serovar (17). The pomona serovar is maintained by swine and bovines, and the equine species is considered an accidental host (23). It is recognized as the most important agent of recurrent uveitis in horses (5), so that its occurrence in healthy animals is smaller than in clinically affected ones (23). In other studies in Brazil, a higher prevalence of this serovar was observed $(2,6,20)$, whereas in this work, anti-Leptospira agglutinins were observed in only $5.42 \%$ of the samples.

Horses are constantly exposed to the pomona serovar, probably due to the presence of rodents. The animals infected by pomona serovar in this study showed titers over 1600, probably because these decreased more slowly and the animals remained reagents for a longer period (3). 
It was suggested that the bratislava serovar is adapted to the equine species (10), however, in this study, the seroreactivity against this serovar was $2.57 \%$, whereas in Rio de Janeiro it was $11.70 \%$ (18). It has been proposed that exposure to this serovar is related to wild animals (3). Other researches on seroepidemics in equines, carried out in Brazil, did not utilize this serovar (18).

Incidence of infection was significantly higher among females, probably due to herd management. This result disagrees with the ones obtained in Canada, where similar results for both sexes were found (16).

In this study, higher exposure to the agent was observed among animals of undetermined breed and those used for work, in agreement with the data found in Canada (16) and USA (3); confirming the importance of management practices on the risk of being seropositive to Leptospira interrogans.

With regard to the age, it was verified that a tendency toward positive response increased with age, confirming the results obtained by other authors $(3,16,19)$, and presuming that with the elapse of time, the animals have higher chances of contracting the infection.

Serologic reactions to various serovars are common, which can be explained by multiple exposure to more than one serovar. It is also possible that some cross-reactivity occurred between the serovars used in MAT (4). Since it is believed that cross-reactivity occurs predominately in lower titers, this evaluation was based on the association between serovars on samples with titers higher than the top limit of confidence interval of titer distribution, according to the Barwick et al. study (4). Therefore, the incidence of reactions to more than one serovar must be considered not only as a result of diagnostic test of the serum but also a reflection of the inaccuracies of the MAT (19).

As an indication of multiple exposure, significant associations were observed for all pairs of antigen tested (pomona, hardjo, icterhaemorrhagiae, gryppotyphosa, canicola, autumnalis, and bratislava), except for gryppotyphosa / pomona and gryppotyphosa / autumnalis, which presented significant associations. In order to evaluate these associations, titers were considered high for values equal to or higher than 1600. 
Cross-reactivity between some of the serovars could explain the large number of low titers (Table 1), also noted in another study (4). Despite the significant association of high titers between serovar pairs indicating multiple exposure (4), associations between the copenhageni and icterohaemorrhagiae serovars, pertaining to the same serogroup (Icterohaemorrhagiae), and between hardjo and wolffi, both of the Serjoe serogroup, suggest the occurrence of crossreactivity among these serovars. In fact, cross-reactivity between the serovars hardjo and wolffi are fairly common, since both belong to the same serogroup and present similar antigens (8).

Additional studies on the epidemiology of this disease in equines are required, including isolation of the bacteria, in order to maximize the measures of control effectiveness and to prevent this disease in the equine and other mammal species (4). In Brazil, Leptospira interrogans, serovar icterohaemorrhagia, was isolated from an aborted equine fetus (12). Further references of isolation and identification of Leptospira in equines from Brazil are not found in literature, with a large blank space on the true participation of some serovars in the genesis of this clinical disease in the equine species.

Table 1. Distribution of positive titers (\%) of 1402 horses from Brazil, evaluated by Microscopic Agglutination Test (MAT) for twelve Leptospira serovars, Botucatu, 2003.

\begin{tabular}{lccccccc}
\hline & \multicolumn{7}{c}{ Titer } \\
Serovar & $\mathbf{1 0 0}$ & $\mathbf{2 0 0}$ & $\mathbf{4 0 0}$ & $\mathbf{8 0 0}$ & $\mathbf{1 6 0 0}$ & $\mathbf{3 2 0 0}$ & Number of reagents \\
\hline Bratislava & 61.10 & 19.40 & 13.90 & 5.60 & 0 & 0 & 36 \\
Castellonis & 63.87 & 24.79 & 8.40 & 1.26 & 1.68 & 0 & 238 \\
Canicola & 46.67 & 46.67 & 6.66 & 0 & 0 & 0 & $15^{1}$ \\
Djasiman & 55.87 & 30.04 & 11.27 & 1.41 & 1.41 & 0 & 213 \\
Gryppotyphosa & 65.38 & 23.08 & 1.92 & 9.62 & 0 & 0 & 52 \\
Copenhageni & 63.53 & 22.35 & 5.88 & 4.71 & 3.53 & 0 & 85 \\
Icterohaemorrhagiae & 60.77 & 30.38 & 6.92 & 1.35 & 0.58 & 0 & 520 \\
Pomona & 50.00 & 28.94 & 15.79 & 3.95 & 0 & 1.32 & $76^{2}$ \\
Pyrogenes & 26.83 & 36.59 & 14.63 & 14.63 & 4.88 & 2.44 & $41^{3}$ \\
Hardjo & 55.56 & 30.16 & 9.52 & 4.76 & 0 & 0 & 63 \\
Wolffi & 50.82 & 29.51 & 18.03 & 1.64 & 0 & 0 & 61 \\
Tarassovi & 71.43 & 19.05 & 4.76 & 4.76 & 0 & 0 & $21^{4}$ \\
\hline${ }^{1}$ 599 sera not tested for canicola; ${ }^{2}$ 5 sera not tested for pomona; ${ }^{3} 599$ sera not tested for pyrogenes; ${ }^{4} 2$ sera not \\
tested for tarassovi serovar.
\end{tabular}


Table 2. $P$ Values for associations between serovar ${ }^{1}$ pairs of Leptospira in samples with titers higher than the upper limit of confidence interval of titer distribution, calculated by the Chisquare or Fisher test, according to the number of observations, Botucatu, 2003.

\begin{tabular}{|c|c|c|c|c|c|c|c|c|c|c|c|c|}
\hline & $\stackrel{5}{5}$ & $\tilde{z}$ & 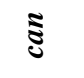 & $: 8$ & हे & 8 & 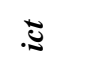 & క్ & हे & $\Xi$ & $\overline{3}$ & $\Xi$ \\
\hline bra & - & 0.12 & 0.98 & 0.86 & 0.97 & 0.06 & 0.21 & 0.92 & 1.00 & 0.96 & 0.94 & 0.99 \\
\hline cas & 0.12 & - & 0.07 & 0.00 & 0.01 & 0.00 & 0.00 & 0.00 & 0.49 & 0.84 & 0.79 & 0.07 \\
\hline can & 0.98 & 0.07 & - & 0.03 & 0.98 & 0.99 & 0.96 & 0.03 & 1.00 & 1.00 & 0.99 & 0.99 \\
\hline dja & 0.86 & 0.00 & 0.03 & - & 0.12 & 0.03 & 0.01 & 0.01 & 0.24 & 0.82 & 0.77 & 0.96 \\
\hline gry & 0.97 & 0.01 & 0.98 & 0.12 & - & 0.05 & 0.82 & 0.91 & 1.00 & 0.96 & 0.95 & 0.99 \\
\hline cop & 0.06 & 0.00 & 0.99 & 0.03 & 0.05 & - & 0.00 & 0.00 & 1.00 & 0.93 & 0.90 & 0.98 \\
\hline ict & 0.21 & 0.00 & 0.96 & 0.01 & 0.82 & 0.00 & - & 0.09 & 0.04 & 0.26 & 0.06 & 0.94 \\
\hline pom & 0.92 & 0.00 & 0.03 & 0.01 & 0.91 & 0.00 & 0.09 & - & 1.00 & 0.21 & 0.13 & 0.98 \\
\hline pyr & 1.00 & 0.49 & 1.00 & 0.24 & 1.00 & 1.00 & 0.04 & 1.00 & - & 1.00 & 1.00 & 1.00 \\
\hline har & 0.96 & 0.84 & 1.00 & 0.82 & 0.96 & 0.93 & 0.26 & 0.21 & 1.00 & - & 0.00 & 0.99 \\
\hline wol & 0.94 & 0.79 & 0.99 & 0.77 & 0.95 & 0.90 & 0.06 & 0.13 & 1.00 & 0.00 & - & 0.98 \\
\hline tar & 0.99 & 0.07 & 0.99 & 0.96 & 0.99 & 0.98 & 0.94 & 0.98 & 1.00 & 0.99 & 0.98 & - \\
\hline
\end{tabular}

Table 3. Occurrence of anti-Leptospira agglutinins in equines, according to origin, number of animals, percentage of reagents, and most frequent serovar. Botucatu 2003.

\begin{tabular}{lrrcl}
\hline Origin & $\mathbf{N}^{\mathbf{0}}$ & $\mathbf{\%}$ & Serovar & Reference \\
\hline São Paulo & 118 & 16.9 & icterohaemorraghiae & Correa et al., 1957 (7) \\
Minas Gerais & 200 & 56.0 & pomona & Barbosa, 1962 (2) \\
São Paulo & 1419 & 37.9 & pomona & Santa Rosa et al., 1968 (20) \\
Rio Grande do Sul & 134 & 9.7 & - & Wiest et al., 1973 (25) \\
Minas Gerais & 195 & 26.1 & pomona & Cordeiro et al., 1974 (6) \\
Goiás & 694 & 14.4 & grippotyphosa & Jardim et al., 1978 (15) \\
São Paulo & 1653 & 4.5 & icterohaemorrhagiae & Giorgi et al., 1981 (12) \\
Rio Grande do Sul & 420 & 37.8 & icterohaemorraghaie & Abuchaim, 1991 (1) \\
Rio de Janeiro & 547 & 42.96 & icterohaemorraghiae & Lilenbaum, 1998 (18) \\
\hline
\end{tabular}




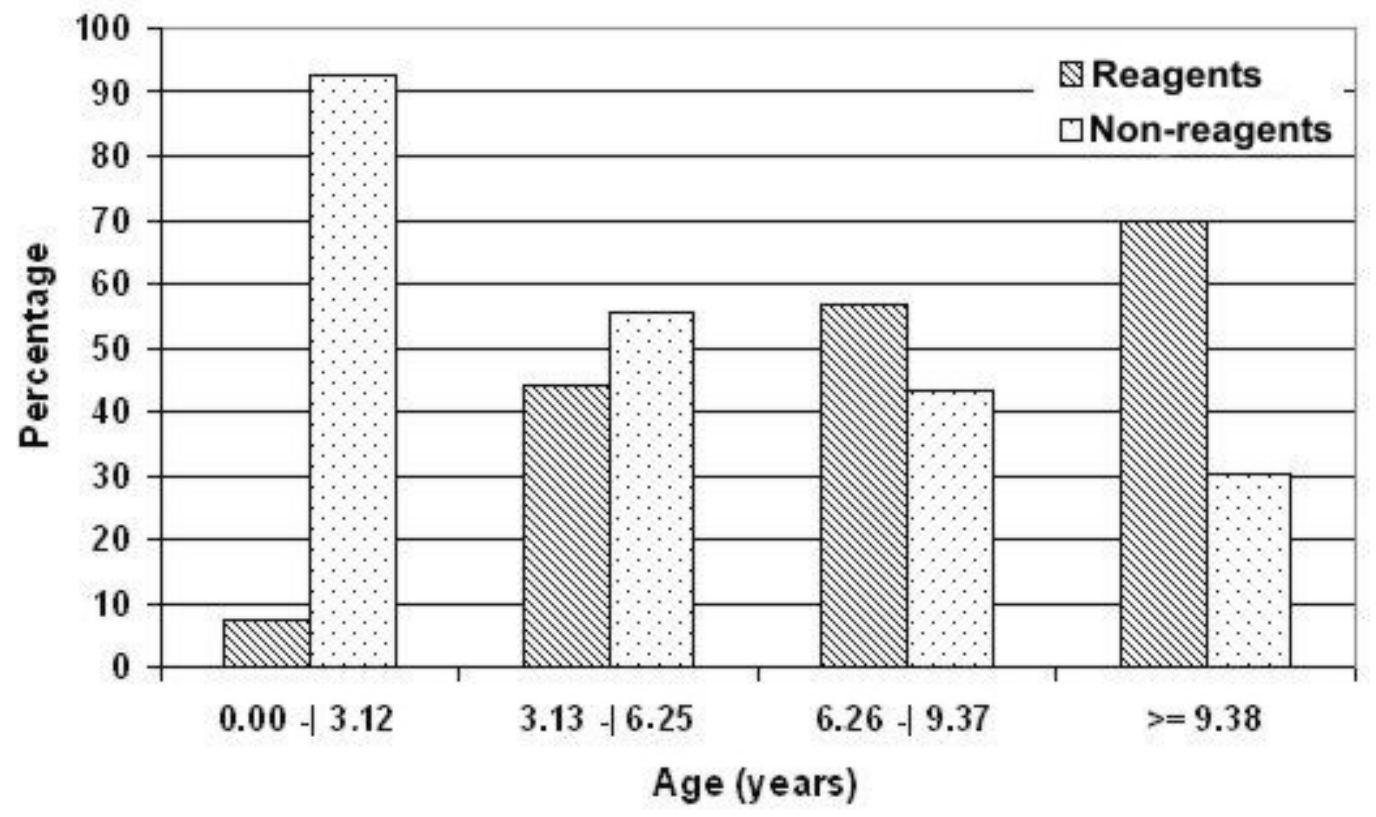

Figure 1. Results of microscopic sero-agglutination for Leptospira spp in 158 samples of equine serum, according to the age, Botucatu, 2003.

\section{CONCLUSION}

High prevalence of anti-Leptospira agglutinins in horses suggests that animals are possible carriers, eliminating the agent with urine into the environment, consequently infecting other animals, including man. These results show the necessity of more studies regarding the epidemiology of this disease in equines and its relationship to the human disease.

\section{ACKNOWLEDGMENTS}

The authors wish to thank the Fundação de Apoio a Pesquisa do Estado de São Paulo FAPESP, for the grants to Aristeu Vieira da Silva (Processo 00/00418-5) and Sandia Bergamaschi Pezerico (Processo 01/12052-8). 
H. Langoni et al. ANTI-LEPTOSPIRE AGGLUTININS IN EQUINE SERA, FROM SÃO PAULO, GOIAS, AND MATO GROSSO DO SUL, BRAZIL, 1996-2001. J. Venom. Anim. Toxins incl. Trop. Dis., 2004, 10, 3, p.217.

\section{REFERENCES}

1 ABUCHAIM DM. Presença de aglutininas antileptospira em soro de equinos no Estado do Rio Grande do Sul. Arq. Fac. Vet. UFRGS, 1991, 9-14.

2 BARBOSA M. Aglutininas e lisinas antileptospira em soros de bovinos, equinos e suínos em Minas Gerais. Arq. Esc. Vet. UFMG, 1962, 14, 1-26.

3 BARWICK RS., MOHAMMED HO., MCDONOUGH PL., WHITE ME. Risk factors associated with the likehood of leptospiral seropositivity in horses in the state of New York. Am. J. Vet. Res., 1997, 58, 1097-103.

4 BARWICK RS., MOHAMMED HO., ATWILL ER., MCDONOUGH PL., WHITE ME. The prevalence of equine leptospirosis in New York State. J. Equine Sci., 1998, 9, 119-24.

5 BERNARD WV. Leptospirosis. Vet. Clin. North Am. Equine Pract., 1993, 9, 435-45.

6 CORDEIRO P., RAMOS AA., BATISTA JÚNIOR JA. Aglutininas antileptospira em soro equino em Minas Gerais. Rev. Agropecu. Bras., 1974, 9, 45-8.

7 CORREA MOA., AMATO NETO V., VERONESI R., FABRI OS. Leptospirose em equinos: inquérito sorológico. Rev. Mil. Remonta Vet., 1957, 15, 45-9.

8 COSTA MCR., MOREIRA EC., LEITE RC., MARTINS NRS. Avaliação da imunidade cruzada entre Leptospira hardjo e L. wolffi. Arq. Bras. Med. Vet. Zootec., 1998, 50, 11-7.

9 DICKESON D., LOVE DN. A serological survey of dogs, cats and horses in south-eastern Australia for leptospiral antibodies. Aust. Vet. J., 1993, 70, 389-90.

10 ELLIS WA., O`BRIEN JJ., CASSELLS JA., MONTGOMERY J. Leptospiral infection in horses in Northern Ireland: serological and microbiological findings. Equine Vet. J., 1983, 15, 317-20.

11 FAINE S. Guidelines for the control of leptospirosis. Geneva: World Health Organization, 1982. 171p. (WHO Offset Publications, 67).

12 GIORGI W., TERUYA JM., MACRUZ R., GENOVEZ ME., SILVA AS., BORGO F. Serological survey for equine leptospirosis (in Brazil) and the isolation of Leptospira icterohaemorrhagiae from an aborted fetus. Biológico, 1981, 47, 47-53.

13 GIRIO RJS., MATHIAS LA., LACERDA NETO JC., VASCONCELLOS SA. Leptospirose experimental em equinos infectados com Leptospira interrogans sorotipo copenhageni: aspectos clínicos e sorológicos. Arq. Inst. Biol., 1999, 66, 216.

14 HATHAWAY SC., LITTLE TWA., FINCH SM., STEVENS AE. Leptospiral infection in horses in England: a serological study. Vet. Rec., 1981, 108, 396-8. 
15 JARDIM EC., SILVA RLD., ALMEIDA MMRD., FICHTNER SS., CÂNDIDA MF. Aglutininas antileptospíricas em equinos no Estado de Goiás. An. Esc. Agron. Vet. UFGO, 1978, 8, 143-9.

16 LEES VW., GALE SP. Titers to Leptospira species in horses in Alberta. Can. Vet. J., 1994, 35, 636-40.

17 LEVETT PN. Leptospirosis. Clin. Microbiol. Rev., 2001, 14, 296-326.

18 LILENBAUM W. Leptospirosis on animal reproduction: IV. Serological findings in mares from six farms in Rio de Janeiro, Brazil (1993- 1996). Braz. J. Vet. Res. Anim. Sci., 1998, 35, 61-3.

19 PILGRIM S., THRELFALL WR. A serologic study of leptospirosis in mares. Vet. Clin. North Am. Equine Pract., 1999, 21, 20-3.

20 SANTA ROSA CA., CASTRO AFPD., CAMPEDELLI FILHO O., MELLO DD. Leptospirose em equinos. Arq. Inst. Biol., 1968, 35, 61-5.

21 SONRIER C., JEULLAIN D., FURET G., FILLONNEAU C., RUVOEN-CLOUET N., GANIERE JP., ANDRÉ-FONTAINE G. Prévalence de différents sérogroupes de leptospires chez le cheval atteint de symptômes non spécifiques. Prat. Vét. Equine, 1998, 30, 19-25.

22 SWAN RA., WILLIAMS ES., TAYLOR EG. Clinical and serological observations on horses with suspected leptospirosis. Aust. Vet. J., 1981, 57, 528-9.

23 SWART KS., CALVERT K., MENEY C. The prevalence of antibodies to serovars of Leptospira interrogans in horses. Aust. Vet. J., 1982, 59, $25-7$.

24 VALON F. Étude clinique, diagnostic et traitements des leptospirosis équines. Prat. Vét. Equine, 1998, 30, 7-14.

25 WIEST JM., ATHAYDE DIAS JC., ABUCHAIM DM. Levantamento sorológico de leptospirose em equinos puro sangue inglês em Porto Alegre, RS. In: CONGRESSO ESTADUAL DE MEDICINA VETERINÁRIA, 3, Porto Alegre, 1973. Anais...Porto Alegre: SOVERGS, 1973: 191-8. 